\title{
Clinical and Endoscopic Features in Helicobacter Pylori Infection: Literature Review
}

\author{
Ghina Tsuraya Salsabila Budiman*, M Begawan Bestari**, Sri Suryanti*** \\ *Faculty of Medicine, Universitas Padjadjaran/Dr. Hasan Sadikin Hospital, Bandung \\ ${ }^{* *}$ Division of Gastroenterology-hepatology, Department of Internal Medicine, Faculty of Medicine, \\ Universitas Padjadjaran/Dr. Hasan Sadikin Hospital, Bandung \\ ${ }^{* * *}$ Department of Clinical Pathology, Faculty of Medicine, Universitas \\ Padjadjaran/Dr. Hasan Sadikin Hospital, Bandung
}

\section{Corresponding author:}

Ghina Tsuraya Salsabila Budiman. Faculty of Mecidine, Universitas Padjadjaran/Dr. Hasan Sadikin Hospital. Jl. Pasteur No. 38 Bandung Indonesia.Phone:+62-22-2038986; facsimile:+62-22-2040151.E-mail: ghinatsr@ gmail.com

\begin{abstract}
Helicobacter pylori is a common infection worldwide and can cause functional dyspepsia, gastritis, and peptic ulcers, leading to gastric cancer. The very diverse clinical outcomes and symptoms of this infection are difficult to distinguish from one another. Endoscopy is one of the methods used to detect Helicobacter pylori infection. Still, it has various endoscopic features, has the possibility of false-negative results, and requires skill to get the maximum results.

This study found that infection can cause various clinical manifestations due to different virulence factors of Helicobacter pylori bacteria. In functional dyspepsia, the patient's most common symptoms are epigastric pain, nausea, and vomiting. In gastritis, Helicobacter pylori infection often causes chronic gastritis with topographic features of pangastritis, and endoscopic features that are usually found are redness, swelling, and regular arrangement of collecting venules (RAC). The most common symptom in peptic ulcers is pain that occurs after eating or at night, and this infection can cause duodenal and gastric ulcers. Currently, the relationship between Helicobacter pylori infection and gastroesophageal reflux disease (GERD) is controversial. In gastric cancer, the most common symptoms are weight loss and repeated vomiting. This infection is more likely to causes intestinal-type gastric cancer.
\end{abstract}

Keywords: Helicobacter pylori, clinical outcomes, endoscopic features

\begin{abstract}
ABSTRAK
Infeksi Helicobacter pylori merupakan infeksi yang sering terjadi di seluruh dunia dan dapat menyebabkan fungsional dispepsia, gastritis, ulkus peptikum, dan dapat menyebabkan kanker lambung. Gambaran klinis yang dihasilkan oleh infeksi bakteri ini sangat beragam sehingga sulit dibedakan antar satu dan yang lainnya. Endoskopi merupakan salah satu metode yang digunakan untuk mendeteksi infeksi Helicobacter pylori, namun memiliki gambaran endoskopi yang beragam, memiliki kemungkinan hasil negatif palsu dan dibutuhkan ahli yang terampil untuk mendapatkan hasil yang maksimal.

Ditemukan gambaran klinis yang beragam akibat perbedaan faktor virulensi dari bakteri Helicobacter pylori. Pada fungsional dispepsia, ditemukan gejala yang paling sering dialami penderita yaitu nyeri epigastrium, mual, dan muntah. Pada gastritis, infeksi Helicobacter pylori sering menyebabkan gastritis kronis dengan gambaran topografi pangastritis dan gambaran endoskopi kemerahan, pembengkakan, dan regular arrangement of collecting venules (RAC). Pada ulkus peptikum, gejala yang sering ditemukan adalah nyeri yang terjadi
\end{abstract}


setelah makan atau pada malam hari, infeksi ini dapat menyebabkan ulkus duodenum, dan ulkus lambung. Saat ini, hubungan antara infeksi Helicobacter pylori dengan gastroesophageal reflux disease (GERD) masih kontroversial. Pada kanker lambung, gejala yang paling sering terjadi yaitu penurunan berat badan dan muntah berulang. Infeksi ini menyebabkan intestinal-type kanker lambung.

Kata kunci: Helicobacter pylori, clinical outcomes, endoscopic features

\section{INTRODUCTION}

H.pylori is a gram-negative bacteria, spiral-shaped, and first discovered in 1982 by Warren and Marshall. ${ }^{1-3}$ H.pylori infection is currently the most common cause of chronic infection in humans. It is estimated to occur in more than $50 \%$ of the world's population, with a higher prevalence in developing countries. ${ }^{4,5}$ H.pylori colonize and damage gastric mucous, leading to inflammation, and is known to be a major risk factor for peptic ulcer, atrophy, and dysplasia, and can eventually lead to gastric malignancy. ${ }^{4,6,7}$ These bacteria colonize and damage gastric mucous, cause inflammation, and are a major risk factor for peptic ulcers, atrophy, and dysplasia, leading to gastric cancer. ${ }^{4,6,7}$ Most people who are infected are asymptomatic. ${ }^{8}$ However, over a long period, $H$. pylori infection can increase the risk of developing multiple clinical outcomes. ${ }^{9}$ The clinical outcomes caused by these bacteria depend on the host's genetic factors, virulence factors in the H. pylori strain, and environmental factors. ${ }^{10,11}$

Identification of these bacteria is needed so that treatment can be given as soon as possible. ${ }^{7}$ The diagnostic test options available for $H$. pylori infection are divided into invasive tests that include endoscopy, histology, culture, rapid urease test, and non-invasive tests, such as urea breath test, stool antigen sets, and serologic. ${ }^{12,13}$ These diagnostic options depend on clinical manifestations, "alarm symptoms" such as vomiting, bleeding, weight loss, or age over 45 years..$^{14,15}$

\section{FUNCTIONAL DYSPEPSIA}

Rome IV defines functional dyspepsia (FD) as a syndrome with one or more of the following symptoms: bothersome postprandial fullness, early satiety, epigastric pain, and epigastric burning without structural disease based on the results of endoscopic examination. Symptoms must occur during the last three months, with at least six months of onset. ${ }^{16,17}$ H.pylori infection may cause dyspepsia symptoms through several mechanisms, such as changes in gastric acid secretion, persistent and active inflammation of the gastric mucosa, and changes in gastroduodenal mucosa.
H. pylori causes an increase in gastrin, decrease in somatostatin, and ghrelin, which causes disturbances in acid secretion, hunger, and gastrointestinal motility. ${ }^{18}$

The most common symptoms experienced in dyspepsia patients is epigastric pain. The pain is probably caused by hypersecretion of stomach acid. ${ }^{18-23}$ Patients with positive $H$. pylori complained of fullness, early satiety, epigastric pain or burning, nausea, persistent or occasional vomiting, loss of appetite, and frequent burping.. ${ }^{19-23}$ Also, based on Koitche Mabeku LB et al, abdominal distention and nausea or vomiting showed a significant positive result of $H$. pylori infection. ${ }^{23}$ These bacteria cause gastrointestinal motility disturbance leading to a redistribution of food in the stomach's distal portion and causing the stomach to be overloaded, resulting in early satiety. ${ }^{24}$ Besides, slowing gastric emptying is thought to have implications for the appearance of symptoms such as nausea, vomiting, and abdominal fullness. ${ }^{24}$ The Leeds Dyspepsia Questionnaire (LDQ) assessment can be used to measure dyspepsia's presence and severity, namely assessing epigastric pain, retrosternal pain, regurgitation, nausea, vomiting, satiety, and dysphagia. ${ }^{20}$ In a study by Faintuch et al, an endoscopic examination was carried out in patients who experienced persistent epigastric burning for more than three months, six months of onset, normal endoscopy was found in 56 patients (20\%), indicating functional dyspepsia. ${ }^{17}$ In a study conducted on patients with dyspepsia, the most common virulence factor in these patients was $\operatorname{cag} A{ }^{25}$

The possible cause of functional dyspepsia is multifactorial, and the role of $H$. pylori in functional dyspepsia is still abe controverted. ${ }^{8,15,26}$ In several studies, H. pylori eradication provides a small but statistically significant benefit in reducing dyspepsia symptoms. ${ }^{5,18}$ Study conducted with meta-analysis, eradication of $H$. pylori works effectively in about $10 \%$ of patients with functional dyspepsia. ${ }^{19}$ An upper gastrointestinal endoscopy is an option for investigating patients older than 40 years old with dyspepsia and those with "alarm symptoms" to diagnose ulcers and other macroscopic disorders such as malignancies..$^{22,27}$ 


\section{GASTRITIS}

Gastritis is inflammation due to the injury of the stomach mucosal lining. ${ }^{8} \mathrm{H}$. pylori will infect and cause acute gastritis, which can heal by itself, characterized by dyspepsia or nausea. ${ }^{8,15,28}$ Acute phase of gastritis in humans rarely been the focus of research because the cases reported in the literature are few. ${ }^{29}$ However, most H. pylori infections will progress to chronic, active gastritis. ${ }^{6,28,30}$ Based on a study conducted in Brazil, patients with positive H. pylori are found mostly in chronic gastritis. ${ }^{31}$

Different chronic gastritis patterns can affect clinical outcomes, including antral-predominant, corpuspredominant, or diffuse (pangastritis or multifocal gastritis). ${ }^{8,15,28,32}$ Antral-predominant gastritis occurs when infection and inflammatory reactions occur only in the antrum..$^{28,32,33}$ Gastric acid secretion in antralpredominant gastritis is normal or slightly increased. This is because the H. pylori bacteria can hydrolyze urea and create a high gastric $\mathrm{pH}$ resulting in decreased somatostatin secretion and increased gastrin secretion. Antral-predominant gastritis can develop into a duodenal ulcer. ${ }^{15,28,32,34,35}$ Diffuse (pangastritis) is a condition when inflammation extends proximal to the stomach and involves the stomach's body and fundus. ${ }^{32}$ Patients with diffuse gastritis are usually characterized by impaired gastric secretion, causing $H$. pylori to colonize the stomach's corpus. ${ }^{15,34}$ Diffuse gastritis can develop into hypochlorhydria, which contributes to gastric malignancy. ${ }^{8,32,34}$ Hypochlorhydria occurs due to H.pylori product, and the inflammatory reaction inhibits gastric parietal cells from secreting gastric acid. Prolonged inhibition of acid secretion, loss of the ability to secrete acid due to chronic inflammation, leading to gastric atrophy resulting in gastric malignancy. ${ }^{35}$

In a study conducted by Carabotti et al, the most common chronic gastritis topography was pangastritis, which occurred $63.9 \%(98 / 154)$ than $36.4 \%(56 / 154)$ of antral gastritis. ${ }^{32}$ In a recent study by Idowu et al, 2019 , pangastritis was found in $76.9 \%(180 / 444)$ of positive H.pylori infection, cagA was the virulence factor of H.pylori bacteria which was mostly found in patients with pangastritis $76.5 \%(111 / 444) .{ }^{36}$ The cagA gene causes gastritis, $v a c A$, and $b a b A$ gene significantly cause chronic inflammation of the gastric mucosa. ${ }^{10,37}$

The most common endoscopic features found in acute H.pylori infection are hemorrhagic spots on the fundus and the stomach's upper body, nodular gastritis, and hypertrophic gastric rugae. ${ }^{38}$ Nodular gastritis is described as a small, round, yellowish nodule. ${ }^{38}$ The endoscopic classification for chronic gastritis has been widely proposed, but the integrated classification is still not accepted worldwide. ${ }^{39}$ The Sydney System classification assesses the antrum, angulus, lesser and greater curvature of the lower gastric body, greater curvature of the upper gastric body, and cardia.

Table 1. The definition and characteristics of the endoscopic features based on the Sydney system classification ${ }^{39,40}$

\begin{tabular}{|c|c|}
\hline Endoscopic features & Definition \\
\hline $\begin{array}{l}\text { Diffuse redness } \\
\text { Absent } \\
\text { present }\end{array}$ & $\begin{array}{l}\text { Redness occurs uniformly involving } \\
\text { the entire mucosa of the fundic gland } \\
\text { Light orange/yellow to white mucosa } \\
\text { redness }\end{array}$ \\
\hline Spotty redness & $\begin{array}{l}\text { Multiple, spotty, minor redness of } \\
\text { fundic gland mucosa }\end{array}$ \\
\hline Red streak & $\begin{array}{l}\text { dinal red streaks in the antrum } \\
\text { pus }\end{array}$ \\
\hline $\begin{array}{l}\text { Patchy redness } \\
\text { Enlarge fold }\end{array}$ & $\begin{array}{l}\text { Localized redness of various sizes } \\
\text { Enlargement of the mucosal fold, } \\
\text { about } 5 \mathrm{~mm} \text { in diameter }\end{array}$ \\
\hline Mucosal edema & $\begin{array}{l}\text { Fundic gland mucosa soft, thick, and } \\
\text { enlarged } \\
\text { The pylorus gland mucosa is smooth } \\
\text { and convexo-concave }\end{array}$ \\
\hline Nodular change & $\begin{array}{l}\text { Protrusion } 2-3 \mathrm{~mm} \text { uniformly at the } \\
\text { gastric angle towards the antrum }\end{array}$ \\
\hline $\begin{array}{l}\text { Regular arrangement of } \\
\text { collecting venules (RAC) } \\
\text { Fundic gland polyposis }\end{array}$ & $\begin{array}{l}\text { Regular red spots like starfish can be } \\
\text { seen on the fundus of the mucosa. } \\
\text { Polyps of various sizes on the mucosa } \\
\text { of the fundus gland }\end{array}$ \\
\hline \multicolumn{2}{|l|}{ Erosion } \\
\hline Flat type & $\begin{array}{l}\text { Grayish mucosal defects of various } \\
\text { sizes }\end{array}$ \\
\hline Raised type & $\begin{array}{l}\text { Mucosal elevation, whitish in the } \\
\text { center }\end{array}$ \\
\hline Hem & Erosion with bleeding \\
\hline & $\begin{array}{l}\text { Red or dark blackish ecchymotic } \\
\text { spots }\end{array}$ \\
\hline
\end{tabular}

Several studies found endoscopic features in H.pylori infection with diffuse redness, spotty redness, enlarged gastric folds, RAC, and mucosal swelling. ${ }^{39,40}$ A study conducted by Hassan et al, 2020, found endoscopic features in gastritis patients are redness, erosion, mucosal nodularity, ulcers, and antral-predominant gastritis pattern more often seen. ${ }^{41}$ Inflammatory reactions and active or healing ulcers, causing endoscopic features such as mucosal atrophy, swelling, spotty redness or red streak, and erosions. ${ }^{42}$

\section{PEPTIC ULCER DISEASE}

Peptic ulcer disease is damage to the gastric or duodenal mucosa that penetrates the muscularis mucosa. ${ }^{43}$ H.pylori infection and the use of nonsteroidal anti-inflammatory drugs (NSAIDs) or a combination of the two are the leading causes of peptic ulcers in developing countries. ${ }^{12,27,44,45}$ H.pylori infection has been shown to cause duodenal ulcers and about two-thirds of causing gastric ulcers. ${ }^{14,45}$ H.pylori with $c a g A, v a c A$, and $b a b A$ positive strain pose a significant risk from developing peptic ulcers, 
especially duodenal ulcers. ${ }^{10,46-49}$ Meanwhile, gastric ulcers are related to the iceA1 and iceA2 genes. ${ }^{10,50}$ H.pylori with cagA and $v a c A$ is localized to the cell mitochondria, causing vacuole formation, damage to the gastric barrier, and pepsin capable of causing cell death and clinical symptoms. ${ }^{46,51}$

The most common symptoms are epigastric pain, bloating, nausea, early satiety, abdominal fullness. ${ }^{12}$ Pain is often described as burning or gnawing, and is usually food-related, occurs 1-3 hours after a meal or at night. The pain may be relieved by food. ${ }^{27}$ In a cohort study conducted by Feder et al, 2018, the clinical characteristics of peptic ulcer disease were gastrointestinal bleeding (53\%), pain (32\%). ${ }^{52}$

Endoscopy with biopsy is required in patients with peptic ulcers to determine the location and benign or malignant etiology. ${ }^{12}$ Research by Feder et al, as many as 97 patients (64\%) patients had gastric ulcers, 36 patients (24\%) had duodenal ulcers, and 17 patients (11\%) had gastric and duodenal ulcers. ${ }^{52}$ In a study conducted by Vinagre et al, found that endoscopy results with gastric ulcers were 17\% (78/442), and duodenal ulcers were 22\% (96/442).$^{53}$ Another study conducted by Faintuch et al, showed that endoscopy results with gastric ulcers were 12 patients $(4 \%)$ and duodenal ulcers were 26 patients $(9 \%){ }^{17}$

Complications from peptic ulcer disease are perforation, penetration, gastric tract obstruction, and ulcer bleeding, causing hematemesis and melena, chronic bleeding, and anemia. ${ }^{12,27}$ Perforation is a severe and fatal complication of peptic ulcer disease. ${ }^{54}$ Peptic ulcer disease is the main cause of upper gastrointestinal tract bleeding. ${ }^{44,45}$ Without proper treatment, peptic ulcer disease is a chronic disease that recurs easily and causes morbidity and mortality due to pain, bleeding, and perforation. ${ }^{14}$

\section{GASTROESOPHAGEAL REFLUX DISEASE}

Gastroesophageal reflux disease (GERD) is the most common gastrointestinal condition in the population..$^{55,56}$ The relationship between GERD and H.pylori is still controversial. ${ }^{26,43,57}$ Most of the studies conducted showed negative results between the relationship between H.pylori and GERD. ${ }^{43}$ In several studies, it is stated that H.pylori infection can protect against GERD. ${ }^{5,58}$ Individuals with GERD may experience improvement of GERD symptoms after eradication of H.pylori infection due to slowly reducing gastric acid secretion. ${ }^{5}$ However, based on eight randomized trials, it is indicated that H.pylori eradication did not have a substantial effect on newlyemerging GERD or worsening existing symptoms. ${ }^{26}$ Based on a study conducted in 2018, there was no relation between GERD and this infection. Still, GERD is a disease determined due to several factors and mechanisms, such as smoking, alcohol consumption, and lifestyle. ${ }^{55}$ Further research is needed regarding these risk factors and their relationship between H.pylori infection and GERD. ${ }^{55}$

\section{GASTRIC CANCER}

In 2012, gastric cancer was the fifth most common malignancy worldwide and was the third most common cause of cancer death worldwide. In other studies, gastric cancer is the second leading cause of cancer death. ${ }^{8,29}$ Colonization of H.pylori bacteria is the most significant and important risk factor for gastric malignancy development. ${ }^{29,59,60}$ Gastric adenocarcinoma can be classified into intestinal-type and diffuse-type. ${ }^{15,61}$ Intestinal-type adenocarcinoma is more common, has been well studied, and H.pylori infection can cause chronic gastritis, atrophy, intestinal metaplasia, dysplasia, and cause intestinal-type gastric cancer. ${ }^{8,15,60,61}$ However, gastric malignancies development depends on H.pylori virulence factors, genetic hosts, dietary factors, micronutrients, and gastrointestinal microbiota. ${ }^{14}$

H.pylori bacteria, which carry the $c a g A$ gene, cause more severe inflammation, and the disease can progress to atrophic gastritis and malignancy. ${ }^{50,62} \mathrm{Also}$, based on a study conducted by Bartpho et al, 2020, found that 64 patients (91\%) with gastric cancer had the babA2 gene, the oipA gen was found in 64 patients (91\%), and $v a c A$ in 42 patients $(60 \%) .{ }^{37} \mathrm{BabA}$ binds to Lewis $\left(\mathrm{Le}^{\mathrm{b}}\right)$ antibodies present in red blood cells and certain epithelial cells. This binding causes dsDNA (doublestranded DNA) breakdown of host cells and gene mutations, contributing to gastric cancer. ${ }^{15}$ Research by Farzi et al., 2018, the oipA gene was found in patients suffering from more severe diseases, including gastric cancer. ${ }^{49}$ OipA causes increased production of IL-8, leading to cell proliferation, angiogenesis, and metastasis, thus contributing to carcinogenesis. ${ }^{15,63}$

Based on the study conducted by Sheikh et al, 2018, gastric cancer's most common symptoms are abdominal pain, weight loss, epigastric pain, and vomit. ${ }^{64}$ Another study found upper gastrointestinal malignancy in 14 (6.7\%) patients over 40 years of age, with dyspepsia symptoms. ${ }^{22}$ Also, patients with new symptoms or "alarm symptoms" (vomit, iron deficiency 
anemia, bleeding, weight loss, or dysphagia) indicate immediate endoscopic examination. ${ }^{8,62}$

A congress held in Kyoto in 2013 developed the Kyoto classification for endoscopic findings. The purpose of this classification is to assess the state of gastric mucosa, which may be at risk for developing gastric cancer. In this classification, an assessment of atrophy, intestinal metaplasia, gastric fold enlargement, and nodularity, redness with or without RAC may be related to H.pylori infection status, which may contribute to the risk of gastric cancer. ${ }^{65}$ Gastric atrophy is considered the final stage of chronic gastritis characterized by loss of glands in the gastric mucosa, causing a decrease in gastric secretion, and is a precancerous condition. ${ }^{8,59}$ On endoscopy examination, gastric atrophy can be seen as transparent blood vessels or yellowish blood vessels. Intestinal metaplasia was seen on endoscopy as grayish-white mucosa with an uneven surface and patchy redness. ${ }^{38,65}$

\section{CONCLUSION}

H.pylori infection can cause various clinical manifestations due to different virulence factors of H.pylori bacteria. It also causes ongoing clinical manifestations, starting from functional dyspepsia, gastritis, peptic ulcers, GERD, and gastric cancer. This infection most commonly develops into chronic gastritis, and the most common symptoms are epigastric pain, nausea, and vomiting.

Diagnosis of this infection is needed to be done as soon as possible. A proper diagnosis is required to detect H.pylori infection to prevent and assess the risk of gastric malignancy. The endoscopic features often found in patients with Helicobacter pylori are redness, swelling, and RAC. It is currently working to harmonize the worldwide accepted assessment of gastritis's macroscopic features.

\section{REFERENCES}

1. Mahamid M, Mari A, Tawfik K, Bragazzi NL, Ghantous M, Abu-Elhija O, et al. Endoscopic and histological findings among israeli populations infected with Helicobacter pylori: does ethnicity matter. Isr Med Assoc J 2019;21:1.

2. Chmiela M, Walczak N, Rudnicka K. Helicobacter pylori outer membrane vesicles involvement in the infection development and Helicobacter pylori-related diseases. J Biomed Sci 2018;25:1-11.

3. Ebule AI, Longdoh AN, Paloheimo IL. Helicobacter pylori infection and atrophic gastritis. Afr Health Sci 2013;13:112-7.

4. Zamani M, Ebrahimtabar F, Zamani V, Miller WH, AlizadehNavaei R, Shokri-Shirvani J, et al. Systematic review with meta-analysis: the worldwide prevalence of Helicobacter pylori infection. Aliment Pharmacol Ther 2018;47:868-76.

5. Chey WD, Leontiadis GI, Howden CW, Moss SF. ACG Clinical Guideline: Treatment of Helicobacter pylori Infection. Am J Gastroenterol 2017;112:212-39.

6. Dudley J, Wieczorek T, Selig M, Cheung H, Shen J, Odze R, et al. Clinicopathological characteristics of invasive gastric Helicobacter pylori. Hum Pathol 2017;61:19-25.

7. Jiang ZX, Nong B, Liang LX, Yan YD, Zhang G. Differential diagnosis of Helicobacter pylori-associated gastritis with the linked-color imaging score. Dig Liver Dis 2019;51:1665-70.

8. Watari J, Chen N, Amenta PS, Fukui H, Oshima T, Tomita T, et al. Helicobacter pylori associated chronic gastritis, clinical syndromes, precancerous lesions, and pathogenesis of gastric cancer development. World J Gastroenterol 2014;20:5461-73.

9. Bagheri N, Azadegan-Dehkordi F, Rafieian-Kopaei M, Rahimian G, Asadi-Samani M, Shirzad H. Clinical relevance of Helicobacter pylori virulence factors in Iranian patients with gastrointestinal diseases. Microb Pathog 2016;100:154-62.

10. Akeel M, Shehata A, Elhafey A, Elmakki E, Aboshouk T, Ageely $\mathrm{H}$, et al. Helicobacter pylori vacA, cagA and iceA genotypes in dyspeptic patients from southwestern region, Saudi Arabia: Distribution and association with clinical outcomes and histopathological changes. BMC Gastroenterol 2019;19:1-11.

11. Osman HA, Hasan H, Suppian R, Hassan S, Andee DZ, Abdul Majid N, et al. Prevalence of Helicobacter pylori cagA, babA2, and dupA genotypes and correlation with clinical outcome in Malaysian patients with dyspepsia. Turkish J Med Sci 2015;45:940-6.

12. Kavitt RT, Lipowska AM, Anyane-Yeboa A, Gralnek IM. Diagnosis and treatment of peptic ulcer disease. Am J Med 2019;132:447-56.

13. Qi Q, Guo C, Ji R, Li Z, Zuo X, Li Y. Diagnostic performance of magnifying endoscopy for Helicobacter pylori infection: A meta-analysis. PLoS One 2016;11:1-14.

14. Mitchell H, Katelaris P. Epidemiology, clinical impacts and current clinical management of Helicobacter pylori infection. Med J Aust 2016;204:1.

15. Testerman TL, Morris J. Beyond the stomach: an updated view of Helicobacter pylori pathogenesis, diagnosis, and treatment. World J Gastroenterol 2014;20:12781-808.

16. Oh JH, Kwon JG, Jung HK, Tae CH, Song KH, Kang SJ, et al. Clinical practice guidelines for functional dyspepsia in Korea. J Neurogastroenterol Motil 2020;26:29-50.

17. Faintuch JJ, Silva FM, Navarro-Rodriguez T, Barbuti RC, Hashimoto CL, Rossini ARAL, et al. Endoscopic findings in uninvestigated dyspepsia. BMC Gastroenterol 2014;14:1.

18. Zullo A, Hassan C, De Francesco V, Repici A, Manta R, Tomao S, et al. Helicobacter pylori and functional dyspepsia: An unsolved issue? World J Gastroenterol 2014;20:8957-63.

19. Kawamura Y, Funaki Y, Yoshimine T, Tamura Y, Yamamoto $\mathrm{S}$, Izawa $\mathrm{S}$, et al. Characteristics and predictive factor of Helicobacter pylori-associated functional dyspepsia in japanese patients. Digestion 2019;100:277-85.

20. Mirbagheri SA, Khajavirad N, Rakhshani N, Ostovaneh MR, Hoseini SME, Hoseini V. Impact of Helicobacter pylori infection and microscopic duodenal histopathological changes on clinical symptoms of patients with functional dyspepsia. Dig Dis Sci 2012;57:967-72.

21. Rodríguez-García JL, Carmona-Sánchez R. Functional dyspepsia and dyspepsia associated with Helicobacter pylori infection: Do they have different clinical characteristics? Rev Gastroenterol México (English Ed 2016;81:126-33. 
22. Ayana SM, Swai B, Maro VP, Kibiki GS. Upper gastrointestinal endoscopic findings and prevalence of Helicobacter pylori infection among adult patients with dyspepsia in northern Tanzania. Tanzan J Health Res 2014;16:1-9.

23. Kouitcheu Mabeku LB, Noundjeu Ngamga ML, Leundji H. Potential risk factors and prevalence of Helicobacter pylori infection among adult patients with dyspepsia symptoms in Cameroon. BMC Infect Dis 2018;18:1-11.

24. Ford AC, Mahadeva S, Carbone MF, Lacy BE, Talley NJ. Functional dyspepsia. Lancet 2020;396:1689-702.

25. Molina-Castro S, Garita-Cambronero J, Malespín-Bendaña W, Une C, Ramírez V. Virulence factor genotyping of Helicobacter pylori isolated from Costa Rican dyspeptic patients. Microb Pathog 2019;128:276-80.

26. Potamitis GS, Axon ATR. Helicobacter pylori and Nonmalignant Diseases. Helicobacter 2015;20:26-9.

27. Majumdar D, Bebb J. Helicobacter pylori infection and peptic ulcers. Med (United Kingdom) 2019;47:292-300.

28. Tan VPY, Wong BCY. Helicobacter pylori and gastritis: Untangling a complex relationship 27 years on. J Gastroenterol Hepatol 2011;26:42-5.

29. Burkitt MD, Duckworth CA, Williams JM, Pritchard DM. Helicobacter pylori-induced gastric pathology: Insights from in vivo and ex vivo models. DMM Dis Model Mech 2017;10:89-104.

30. Falkeis-veits C, Vieth M. Non-malignant Helicobacter pyloriAssociated Diseases. 2019;

31. Basílio ILD, Catão MDFC, Carvalho JDDS, Freire-Neto FP, Ferreira LC, Jerônimo SMB. Risk factors of Helicobacter pylori infection in an urban community in Northeast Brazil and the relationship between the infection and gastric diseases. Rev Soc Bras Med Trop 2018;51:183-9.

32. Carabotti M, Lahner E, Porowska B, Colacci E, Trentino $\mathrm{P}$, Annibale B, et al. Are clinical features able to predict Helicobacter pylori gastritis patterns? Evidence from tertiary centers. Intern Emerg Med 2014;9:841-5.

33. Sipponen P, Maaroos HI. Chronic gastritis. Scand J Gastroenterol 2015;50:657-67.

34. Cho SJ, Choi IJ, Kim CG, Kook MC, Lee JY, Kim BC, et al. risk factors associated with gastric cancer in patients with a duodenal ulcer. helicobacter 2010;15:516-23.

35. Smolka AJ, Schubert ML. Helicobacter pylori-induced changes in gastric acid secretion and upper gastrointestinal disease. Curr Top Microbiol Immunol 2017;400:227-52.

36. Idowu A, Mzukwa A, Harrison U, Palamides P, Haas R, Mbao M, et al. Detection of Helicobacter pylori and its virulence genes (cagA, dupA, and vacA) among patients with gastroduodenal diseases in Chris Hani Baragwanath Academic Hospital, South Africa. BMC Gastroenterol 2019;19:1-10.

37. Bartpho TS, Wattanawongdon W, Tongtawee T, Paoin C, Kangwantas K, Dechsukhum C. Precancerous Gastric Lesions with Helicobacter pylori vacA +/ babA 2+/ oipA + Genotype Increase the Risk of Gastric Cancer. Biomed Res Int. 2020;2020.

38. Lee SY. Endoscopic gastritis, serum pepsinogen assay, and Helicobacter pylori infection. Korean J Intern Med 2016;31:835-44.

39. Kato T, Yagi N, Kamada T, Shimbo T, Watanabe H, Ida K. Diagnosis of Helicobacter pylori infection in gastric mucosa by endoscopic features: A multicenter prospective study. Dig Endosc 2013;25:508-18.
40. Mao T, Wang Y, Yin F, Zhao Q, Yang L, Ding X, et al. Association of Endoscopic Features of Gastric Mucosa with Helicobacter pylori Infection in Chinese Patients. Gastroenterol Res Pract 2016;2016:10-7.

41. Hassan TM, Al-Najjar S, Al-Zahrani I, Alanazi FB, Alotibi M. Helicobacter pylori chronic gastritis updated Sydney grading in relation to endoscopic findings and $\mathrm{H}$. pylori IgG antibody: diagnostic methods. J Microsc Ultrastruct 2016;4:167.

42. Adu-Aryee NA, Aabakken L, Dedey F, Nsaful J, Kudzi W. Comparison of endoscopic based diagnosis with Helicobacter urease test for Helicobacter pylori infection. BMC Res Notes 2016;9:1-6.

43. Sjomina O, Heluwaert F, Moussata D, Leja M. Helicobacter pylori infection and nonmalignant diseases. Helicobacter 2017;22:1-5.

44. Hung KW, Knotts RM, Faye AS, Pont AR, Lebwohl B, Abrams JA, et al. Factors associated with adherence to Helicobacter pylori testing during hospitalization for bleeding peptic ulcer disease. Clin Gastroenterol Hepatol 2020;18:1091-1098.e1.

45. Chason RD, Reisch JS, Rockey DC. More favorable outcomes with peptic ulcer bleeding due to Helicobacter pylori. Am J Med 2013;126:811-818.e1.

46. Ofori EG, Adinortey CA, Bockarie AS, Kyei F, Tagoe EA, Adinortey MB. Helicobacter pylori Infection, Virulence Genes' Distribution and Accompanying Clinical Outcomes: The West Africa Situation. Biomed Res Int 2019;2019.

47. Abdollahi H, Hashemzadeh M, Khoshnood S, Savari M. Characterization of Helicobacter pylori genotypes from Iranian patients with gastric clinical diseases: Predominance of vacA s1a and cagA EPIYA-ABC genotypes. Gene Reports 2019;16:100458.

48. Yilmaz N, Koruk Özer M. The prevalence of Helicobacter pylori babA, homB, aspA, and sabA Genes and Its Relationship with Clinical Outcomes in Turkey. Can J Gastroenterol Hepatol 2019;2019.

49. Farzi N, Yadegar A, Aghdaei HA, Yamaoka Y, Zali MR. Genetic diversity and functional analysis of oipA gene in association with other virulence factors among Helicobacter pylori isolates from Iranian patients with different gastric diseases. Infect Genet Evol 2018;60:26-34.

50. Chang WL, Yeh YC, Sheu BS. The impacts of H. pylori virulence factors on the development of gastroduodenal diseases. J Biomed Sci 2018;25:1-9.

51. Palframan SL, Kwok T, Gabriel K. Vacuolating cytotoxin A (VacA), a key toxin for Helicobacter pylori pathogenesis. Front Cell Infect Microbiol 2012;2:92.

52. Feder R, Posner S, Qin Y, Zheng J, Chow SC, Garman KS. Helicobacter pylori-associated peptic ulcer disease: A retrospective analysis of post-treatment testing practices. Helicobacter 2018;23:1-7.

53. Vinagre RMDF, Vilar-e-Silva A, Alves FA, Martins LC. Role of Helicobacter pylori Infection and Lifestyle Habits in the Development of Gastroduodenal Diseases in a Population From the Brazilian Amazon. Arq Gastroenterol 2013;50:170-4.

54. Wong CS, Chia CF, Lee HC, Wei PL, Ma HP, Tsai SH, et al. Eradication of Helicobacter pylori for prevention of ulcer recurrence after simple closure of perforated peptic ulcer: A meta-analysis of randomized controlled trials. J Surg Res 2013;182:219-26.

55. Scida S, Russo M, Miraglia C, Leandro G, Franzoni L, Meschi $\mathrm{T}$, et al. Relationship between Helicobacter pylori infection and GERD. Acta Biomed 2018;89:40-3. 
56. den Hollander WJ, Sostres C, Kuipers EJ, Lanas A. Helicobacter pylori and Nonmalignant Diseases. Helicobacter 2013;18:24-7.

57. Shmuely H, Katicic M, Filipec Kanizaj T, Niv Y. Helicobacter pylori and Nonmalignant Diseases. Helicobacter 2012;17:22-5.

58. Rubenstein JH, Inadomi JM, Scheiman J, Schoenfeld P, Appelman H, Zhang M, et al. Association between Helicobacter pylori and Barrett's esophagus, erosive esophagitis, and gastroesophageal reflux symptoms. Clin Gastroenterol Hepatol 2014;12:239-45.

59. Dîrnu R, Secureanu FA, Neamţu C, Totolici BD, Pop OT, Mitruţ $\mathrm{P}$, et al. Chronic gastritis with intestinal metaplasia: Clinico-statistical, histological and immunohistochemical study. Rom J Morphol Embryol 2012;53:293-7.

60. Li L, Yu C. Helicobacter pylori Infection following Endoscopic Resection of Early Gastric Cancer. Biomed Res Int 2019;2019.

61. Valenzuela MA, Canales J, Corvalán AH, Quest AFG. Helicobacter pylori -induced inflammation and epigenetic changes during gastric carcinogenesis. World J Gastroenterol 2015;21:12742-56.

62. Yula E, Nagiyev T, Kaya ÖA, Inci M, Çelik MM, Köksal F. Detection of primary clarithromycin resistance of Helicobacter pylori and association between cagA + status and clinical outcome. Folia Microbiol (Praha) 2013;58:141-6.

63. Lee KE, Khoi PN, Xia Y, Park JS, Joo YE, Kim KK, et al. Helicobacter pylori and interleukin-8 in gastric cancer. World J Gastroenterol 2013;19:8192-202.

64. Sheikh AF, Yadyad MJ, Goodarzi H, Hashemi SJ, Aslani S, Assarehzadegan MA, et al. CagA and vacA allelic combination of Helicobacter pylori in gastroduodenal disorders. Microb Pathog 2018;122:144-50.

65. Toyoshima O, Nishizawa T, Koike K. Endoscopic Kyoto classification of Helicobacter pylori infection and gastric cancer risk diagnosis. World J Gastroenterol 2020;9327:1. 